\title{
Study on the Collaborative Mechanism between Teaching and Scientific Research in Private Higher Vocational Colleges
}

\author{
Aimin Wei \\ Email:524496523@qq.com, 510925, Guangzhou, Guangdong province, Guangzhou City Construction College
}

\begin{abstract}
With the development of economy and progress of society, our country and government have given more and more importance to education as well as talents with higher education. Addressing this issue, it is especially important for universities and government to take innovative actions. Therefore, in this paper, a series of measures have been provided based on actual situation. In practice, the main educational goal of higher vocational colleges is skill teaching, which aims to cultivate professional technicians for social production. It is different from that of ordinary universities and colleges. Thus, different kinds of teaching guidelines should be adopted to cultivate particular talents for social needs. In order to strengthen the adaptation of education to social demand, education in higher vocational colleges should be collaborated with scientific research with improvement of educational goals and educational means. Besides, school education should be combined with market demand with innovative educational mechanism.
\end{abstract}

Key words-higher vocational education; teaching and scientific research; innovative mechanism; higher vocational colleges; practical mode

\section{INTRODUCTION}

With the popularity of higher education, the amount of undergraduates has been constantly increasing, which is unsuitable for modern social economic development and current positions available. However, our society has an increasingly higher demand for senior technicians, and higher vocational education has also received more and more attention from all walks of life. Therefore, it is the main emphasis for higher vocational education to collaborate teaching with scientific research by deepening educational revolution and creating educational mechanism. Talents, market demands and scientific research should be integrated together. In this paper, the author aims to provide some suggestions for innovative mechanism' s optimization by analyzing problems existing in private higher vocational education from the connotation of collaborative mechanism between higher vocational education and scientific research.

\section{THE CONNOTATION OF COLLABORATIVE INNOVATIVE MECHANISM BETWEEN HIGHER VOCATIONAL EDUCATION AND SCIENTIFIC RESEARCH}

The essence of collaborative innovative mechanism of scientific research is to promote market appeal of higher vocational education so as to cultivate students' comprehensive qualities with better skills. The department of scientific research is right the technology innovation base of social production since most revolutionary technologies are generated in laboratory during social production. Thus, by combining talent cultivation with scientific research, higher vocational education can basically promote students' values and provide professional talents that market wants. However, promotion of educational capability not only needs efforts from scientific research department and colleges, but it also needs political support from government. In this way, higher vocational education can be deeply integrated with scientific research so as to establish a talent cultivation plan which is adaptable for present school education and social demand. At present, traditional manufacture industry is developed slowly; besides, higher vocational education is not suitable for market demand. So cultivation effect of professional talents can' $t$ be perfected through traditional educational mode. Under the new circumstance, there has been an increasingly higher demand for senior technicians. Contemporary higher vocational colleges should enhance their adaptations to social demand so as to cultivate world-class professional talents for industrial demand. Talent, demand and scientific research should be seen as the educational innovation basis to train students' core competition.

\section{PROPOSAL OF MANY PROBLEMS}

With the fast development of economy and society, scale of higher vocational education has been constantly enlarged. Under this trend, Chinese education has been changed again on the whole, but this time more emphasis has been placed on internal forms. This is a great revolution of higher education, which pays great attention to talent cultivation and scientific innovation. As for the internal form of higher vocational education, teaching has to be combined with scientific research innovation. There may be some difficulties during the establishment of such system, so higher vocational colleges should manage to overcome those troubles. As for higher education, each school has its own unique educational mode, scientific research, social practice and ideological education, all of which should be manifested by students' performances. Different people have different opinions on these issues, for example, it has quite a lot controversy about scientific research, which is the focus of social attention In August, 2011, Opinions on Promoting Revolution and Innovation of Higher 
Vocational Education So As to Lead the Scientific Development of Vocational Education by Ministry of Education was issued by Ministry of Education. According to the paper, a related mode should be established by higher vocational colleges between study and scientific research with more importance to technological training so as to promote social reformation and development. At the same time, the occupation of teacher should also be cultivated so as to improve the quality and development of teaching.

On the other side, education and scientific research have great relations with the society, so talents graduating from higher vocational colleges have important significance in promoting social development. With the development of economy, our society has an increasingly higher demand for high technologies and higher education. Therefore, social status of higher vocational colleges has also been elevated. By combining higher education with scientific research with constant development, they can be complementary to each other, and thus the whole social economy can be improved. However, Chinese higher vocational colleges are weak in scientific research with a late development. Under this circumstance, our country and government should vigorously support the scientific research in higher vocational colleges so as to cultivate more professional talents to meet social development.

\section{A. Teaching in higher vocational colleges gives little attention to practice}

Most higher vocational colleges in China adopt traditional teaching mode. That is, they only teach students contents on the textbook without research and discussion of contemporary subjects. Thus, the information is usually backward, lacking practicability and innovation. With more attention to theoretical knowledge but less attention to practice, students can' $t$ apply what they' ve learned to practice; let alone explain the latest methods or technologies with written theories. Nowadays, information communication can be conveyed vividly with various kinds of forms in network environment. By comparison, traditional teaching mode is less effective with dated contents.

\section{B. The teaching methods and teaching contents are not adhered to teaching goals}

Although there is a large proportion of experimental lessons besides cultural theoretical lessons in current higher vocational education, the experimental equipment are very old with long-term update. Therefore, the real effect of practical teaching can' t be brought out with the backward teaching methods and teaching facilities. They just serve as the supplement of traditional teaching contents, which seriously impede the cultivation of students creation and individuality. The goal of higher vocational colleges is to cultivate talents with comprehensive qualities and advanced professional skills. However, due to the limitation of teaching contents, teaching methods, outdated experimental equipment as well as lack of construction capitals, the final result has seriously deviated from the teaching goals. As a result, the knowledge and skills students have learned in school can' $t$ be applied to practical production, which is bad for their employment and future development, leading to a conflict between demand and supply. In addition, the evaluation system is imperfect since its evaluation of students' capabilities relies too much on the paper results, which affects and deviates from the teaching goal of cultivating talents with professional skills.

\section{Lack of practical training basis}

It is an effective means for students to promote skills by practicing in enterprises. But in reality, students seldom have the chance to practice in enterprises because the incompatibility between students' amount and enterprises. Even though some of them are lucky enough to get the chance, their knowledge and skills can' $t$ be given into full play due the limited time and outdated experimental equipment. Besides, practical teaching usually lacks behind present scientific development as a result of little communication among schools, social enterprises and scientific research institutes.

\section{SUGGESTIONS TO OPTIMIZING INNOVATIVE MECHANISM}

\section{A. Perfect the innovative mechanism in schools and research institutes for a systematic development}

At present, higher vocational colleges are taking majors, practical experience and social demand as their centers during development. However, more attention should be paid to students' mind and practical experience, combining theoretical teaching with practical teaching together. The new educational reform in higher colleges aims to enhance students ' independence, comprehensive capabilities and practical skills, so practice teaching method is more suitable for current educational trend, which fundamentally changes the cultivation methods of learning goals and learning methods of higher vocational education. It perfects the innovative mechanism and operational mechanism combined school education, social practice and scientific research all together with more emphasis on the practicability of teaching contents.

\section{B. Strengthen the revolution of educational means in higher vocational colleges.}

During the process of practice teaching, not only do students can learn theoretical knowledge, but they can also feel the application environment deeply so that they can develop themselves in different ways, forming capability of innovation and individuality. Students may raise individualized problems during study and exploration with active exploration on the deep meaning of knowledge as well as the knowledge structure, and thus they can apply what they' ve learned to practice. The creative collaborative mechanism for teaching and scientific research in higher vocational colleges has completely manifested the spirit of scientific research. Since higher vocational education is different from quality education with different teaching goals, so it has to be developed in an independent and professional way, which is also the development trend of modern education. While appealing to the open and 
individualized educational guidelines of higher education, it can also promote the educational effect of professional skills in higher vocational colleges.

\section{Carry out teaching mode with real enterprise project}

Higher vocational schools should actively carry out a series of activities by cooperating with enterprises. Students can be arranged to work in a real position in an enterprise so that they can truly know about the production site with better application ability of skills. Besides, the teaching concept of higher vocational education should be transferred from skill mastery to skill employment so as to strengthen the practicability of practice teaching. In the practical operation, with the help of instructor or production teacher, students can finish processing or production successfully with better application capability of skills.

\section{A SERIES OF LESSONS CAN BE LEARNED FROM PRACTICAL EXPERIENCE}

According to practical analysis, constant innovation of teaching and scientific research in higher vocational colleges is the practical demand for social development, which has been an assurance for social senior technicians. According to the combination and explanation of scientific research and innovation, scientific research should be seen as the impetus, while innovation should be regarded as assistance. In other word, by combining scientific research and innovation, higher vocational colleges can form a new program with highly efficient operation.

\section{A. Better result can be brought out by combining teaching with scientific research together}

Scientific research for education should be conducted by teaching with constant innovations; while in higher vocational education, teachers are surely in a dominant position. Therefore, teachers' academic level and professional skills should also be constantly developed to meet the high demand of higher vocational education.

\section{B. To improve the teaching by scientific research so as to further reach the vocational goals of teachers.}

The nature of teaching is different from other jobs, so teachers should constantly enrich their knowledge through different scientific researches during educational process. Whoever you are a new teacher or a senior one, you should make progress and improvement all the same. Scientific research is indeed indispensable for the promotion. Teachers should carry out scientific research constantly to accumulate working experience and enrich knowledge level, applying their knowledge to practical teaching. Besides, teachers should lead students to conduct study so that students can enjoy the pleasure of scientific research on their own. Such kind of teaching mode can not only promote students' professional skills, but it can also improve teaching level in higher vocational colleges on the whole.

C. Scientific research should be added to class teaching so as to truly promote students' professional skills.
One characteristic of higher vocational education is that it combines teaching with research. Its main purpose is to provide more talents with fine skills for the society. In modern society, the most distinctive characteristic of high-quality talents is their innovative capability and outstanding capability of scientific research. Therefore, it is possible to add scientific research to class teaching. By this way, both students' mind and body can be fully developed with stronger abilities under the tutor' $s$ instructions, which is more colorful than simple textbook knowledge study. Meanwhile, the teaching level of teachers can also be elevated.

Conclusion

According to actual situation and investigation, higher vocational education is a different educational mode, which is especially standard regarding school education and cultivation of senior professional talents. Besides, it is of strong responsibility. It learns fine systems and educational modes from other higher colleges. In the paper, it focuses on the study of collaborative mechanism between higher vocational education and scientific research by studying problems existing in private higher vocational education. It aims to strengthen the new innovative operation mechanism combined school education, social practice and scientific research all together so as to achieve a real enterprise-project teaching mode and to enhance revolution of higher vocational education. By this way, students can be provided with better learning environment and scientific equipment at a higher standard. Through practice by themselves, students' skills can be promoted, and thus the teaching level of the whole school can be elevated. Moreover, it doesn' $t$ mean the most effective way is to make students practice in enterprises; instead, their operational ability can also be improved by practicing in class. Finally, the fundamental purpose of higher vocational colleges can be achieved by these ways with combination of study and scientific research.

\section{REFERENCES}

[1] Top Design of Modern Vocational Education- Realizing the Dream of a Successful Higher Vocational Education [J]. Modern Education. August, 2013.

[2] Chen Hongyu, Exploration on Five Innovative Mechanisms of Chinese Vocational Education[J]. Modern Education Science. 2010(S1)

[3] Feng Liyuan, Problems and Countermeasures during the Establishment of Creative Staff in Higher Vocational Colleges[J]. Chinese Grown-up Education. 2013(20)

[4] Wang Shunxu, Practice and Innovation of Academic Atmosphere in Higher Vocational Colleges[J]. School Journals of Jiyuan Vocational College. 2007(03)

[5] Wang Yonghong, Zeng Dongsheng. Reflections on Running a School With Close Cooperation among National Backbone Colleges[J]. Version of Nature and Science from Jiangsu Educational College. 2012(01)

[6] Zou Chengjun, Jiang Shengwen, Zhangxia. Exploration on Cooperation among Higher Vocational Colleges[J]Science and Technology of Higher Colleges, 2012,(120:53-54.

[7] People's Republic of China Ministry of Education.2013 Higher Education has general enrollment eligibility list of colleges and 
universities. http://www.moe.gov.cn/publicfiles/ business/htmlfiles/moe/moe_634/201305/151636.html.

[8] Q.L.Wei. Data envelopment analysis [M].Beijing:Science Pr.2004.

[9] Charnes,A,Cooper,W.W, Rhodes,E.Measurement the efficiency of decision making unit [J].European Journal of Operational Research,1978(2):429-444.

[10] D.B.Ning,Y.Li.Efficiency of China Construction Evaluation Based on DEA Method [J].Construction Industry,2012 (7).

The research program has been funded by Guangzhou City Construction College Key project by

2013-2014 year [Z201301].

\section{ABOUT THE AUTHOR}

Wei Aimin, female, born in 1977, Cantonese, lecturer, building economy research as the main research direction.

Wei Aimin Email address: 524496523@qq.com Phone number: 13925119162

Postal code: 510925 Address: Department of Architectural Engineering, Guangzhou City Construction College, 166 Huanshi East Road, Conghua, Guangzhou, 